\title{
T1 - Estudios arqueológicos de pre construcción del Gran Canal Interoceánico de Nicaragua
}

\author{
Sagrario Balladares-Navarro*, Leonardo Lechado-Ríos \\ Universidad Nacional Autónoma de Nicaragua (UNAN), Managua
}

*Autor al que se dirige la correspondencia: sabanarro@yahoo.es

\section{Resumen}

Tos resultados obtenidos en las dos primeras jornadas de campo de los estudios arqueológicos de pre construc—ción del Gran Canal Interoceánico de Nicaragua (GCIN), dan cuenta de la transformación de un espacio en el litoral Pacífico sur del país, ya que en él fueron encontradas varias elevaciones artificiales alrededor de un manglar, expresión de una alta y dinámica producción de sal en el pasado, iniciada en el $800 \mathrm{dC}$. El rescate del patrimonio arqueológico en la ruta proyectada se inició en noviembre de 2015 desde la UNAN-Managua, financiado por la concesionaria HKND Group y el CNU en cumplimiento a las leyes vigentes nacionales e internacionales. Es un primer paso en contribución al Plan Nacional de Desarrollo Humano, ya que entre otras cosas, se trata de recuperar la historia de los pueblos originarios que existieron a lo largo de esta ruta y de quienes aún se conoce poco.

Palabras claves: Rescate, patrimonio, transformación, medio ambiente

\begin{abstract}
A rchaeological studies for pre construction of the Great Interoceanic Nicaragua Channel (GCIN), realize the transformation of an area on the Pacific coast south of the country, where they were found several artificial elevations around a mangrove swamp, as a result of high and dynamic salt production in the past, initiated in the $800 \mathrm{AD}$. The rescue of archaeological heritage in the planned route began in November 2015 from the UNAN, Managua, financed by the concessionaire HKND Group and the CNU in accordance with national and international laws in force. It is a first step in contribution to the National Human Development Plan, since among other thing, it is to recover the history of the native peoples that existed along this route and those that still little is known.
\end{abstract}

Keywords: Rescue, patrimony, transformation, environment 